\title{
A TANULÁSI MOTIVÁCIÓK ÉS A MUNKAERŐ-PIACI ELVÁRÁSOK ÖSSZEFÜGGÉSEI
}

\section{Szerzők:}

Pálosi Rita

Debreceni Egyetem

R. Fedor Anita

Debreceni Egyetem Egészségügyi Kar

Első szerző e-mail címe:

rita.palosi@gmail.com

\section{Lektorok:}

Horváth László

Debreceni Egyetem

Jávorné Erdei Renáta

Debreceni Egyetem

Szilágyi Barnabás

Debreceni Egyetem

Mező Katalin

Debreceni Egyetem

Pálosi Rita, R. Fedor Anita (2017): A tanulási motivációk és a munkaerö-piaci elvárások összefüggései. Különleges Bánásmód, III. évf. 2017/4. szám, 51-63. DOI 10.18458/KB.2017.4.51

\begin{abstract}
Absztrakt
A tanulási motivációról hazai és külföldi szakirodalomban egyaránt olvashatunk. Jelen tanulmányban mi is azt vizsgáljuk, hogy milyen a fiatalok tanulási attitüdje illetve, hogy ez milyen összefüggésben van a fiatalok munkaeröpiacon történő elhelyezkedésével. A téma aktualitását az adja, hogy a pályaválasztás elött álló fiatalok többnyire felsőfokú képzésekre jelentkeznek, és szakmát kevesebben akarnak tanulni. Valóban mindenki ennyire motivált a tanulásban? Melyek azok a belső és külső tényezők, amelyek motiválják az egyént a tanulásában? Vajon a családi háttér hatással van-e a tanuló teljesítményére? Ezekre a kérdésekre kerestük a választ. Eredmények: Elsődleges eredményeink szerint a vizsgált fiatalok jelentős többsége szeretne továbbtanulni az érettségi után. Ebben látják későbbi munkaerő-piaci érvényesülésüket. A legtöbbek által megjelölt szakirány az egészségügyi és a gazdasági terület. Tanulási motivációs rangsoruk első helyén a „sikeres akarok lenni” attitüd áll.
\end{abstract}

Kulcsszavak: tanulási motiváció, munkaerőpiac, ifjúság

Diszciplína: pedagógia, pszichológia, szociológia,

\section{Abstract}

Publications on student motivation in learning are available in Hungarian as well as in English-language scientific literature. The present study is aiming to focus on the connection 
between motivation of learning and finding work at the labor market. Actuality of the topic is based on the fact that young people in front of a career choice mostly apply for higher education and there are only fewer of them willing to learn a profession. Is everyone really that motivated to learn? What are the external and internal factors that motivate the individual to learn? Does family background have an impact on the performance of the student? We have been looking for answers to these questions. According to our primary results, the majority of the examined young adults are willing to continue to study after high-school graduation. That is how they think they will later prevail entering the labor market. The most common specializations chosen are health and economy. At the first place of their learning motivation ranking we find "want to be successful attitude".

Keywords: motivation in learning, factors in learning motivation, youth

Disciplines: pedagogy, psychology, sociology,

\section{BEVEZETÉS}

Írásunkban a fiatalok tanulási motivációjának feltérképezésére vállalkozunk. A témához kapcsolódó elméleti háttér felvillantása után, a jelenleg is folyamatban lévő empirikus munkánk eddigi eredményeit kívánjuk bemutatni. Kutató munkánkban a fiatalok, ezen belül is a végzés előtt álló középiskolások tanuláshoz kötődő attitüdjét, munkaerő-piaci elvárásait, értékválasztását vizsgáljuk Debrecenben.

Tanulmányunkban elsősorban a tanulási motiváció kérdéskörére koncentrálunk, a munkaerö-piaci elvárások mintázatáról ennél rövidebben szólunk, az értékválasztással kapcsolatos eredményeinket pedig egy későbbi írásunkban közöljük. Vizsgálatunkkal egy korábbi nemzetközi kutatáshoz kapcsolódtunk (Youth in Central and Eastern European CrossborderAreas), melynek adatfelvétele egy-egy határ menti lengyel, ukrán, magyar településen történt, végzés előtt álló gimnazista és középiskolás fiatalok körében. Magyarországon Nyíregyháza lett a kiválasztott település. ${ }^{1}$ Az említett nemzetközi kutatás kérdőívét részben adaptáltuk, mely a későbbiekben lehetővé teszi számunkra, hogy a vizsgálat hazai vonatkozású eredményeit összevessük kutatásunk eredményeivel. Mintánkba két gimnázium került be (egy „általános”- és egy szakgimnázium), melyek 11. osztályos hallgatói körében teljes körü lekérdezést végeztünk.

Az adatgyüjtés 2017 májusában történt, kvantitatív, survey módszerrel. A két iskolában 100100 kérdőív került kiosztásra, mely 44 kérdést tartalmazott, melyből jelenlegi munkánkban 17 kérdés elemzésére koncentrálunk. A kérdések a következő dimenziók köré csoportosultak: Tanulási motiváció, Személyiség jegyek, Munkaerő-piaci elvárások, Családi dimenzió. Jelen írásban az ,általános” gimnázium adatait elemezzük, tanulmányunkban a hozzájuk kapcsolódó eredmények olvashatók. A teljes minta vizsgálata jelenleg is folyamatban van, melynek eredményeit a későbbiekben kívánjuk publikálni.

Az adatok rögzítésére és elemzésére az SPSS 24 statisztikai programot használtuk ${ }^{2}$. Ezen belül az adatok tényszerü leírását egyszerü megoszlás, az összefüggések vizsgálatát kereszttábla illetve Khi-négyzet próba segítségével végeztük el.Az ,általános” gimnáziumból beérkező kérdőívekből 88 volt értékelhető. A válaszadók közül 54 fő nő 32 fö férfi volt (2 fö nem válaszolt). A megkérdezett fiatalok többsége Debrecenben él (78 fö), faluról összesen 8 fö származik (2 fő nem válaszolt).

\footnotetext{
${ }^{1}$ A hazai adatokat Kovács-Dusa-Ludescher (2016), valamint Engler-R.Fedor-Markos (2016) elemezte a külföldi munkavállalás, regionális kötődés, szabadidős tevékenység, továbbtanulás, életcélok témában.

${ }^{2}$ Ezúton szeretnénk köszönetet mondani Kósa Szilviának az adatok SPSS-programban történő rögzítésért.
} 


\section{A tanulási motiváció}

Vizsgálatunk elméleti háttere multidiszciplináris, hiszen a témának pedagógiai, pszichológiai, szociológiai, élettani aspektusai is vannak. Írásunkban terjedelmi okok miatt nem vállaljuk az elméleti háttérként szolgáló valamennyi megközelítés teljes körü bemutatását, e tekintetben inkább egyfajta ízelítőként szolgálunk.

\section{Történeti áttekintés}

XVII. században Comenius azt gondolta, hogy „minden iskola játszóhellyé lehet, vagyis a tanítás és tanulás minden feladat játékként és tréfaként hajtható végre" (Réthyné, 2003, 12.o.). Szintén ebben a században élt és munkálkodott Locke, aki azt vallotta, hogy a gyermeki kíváncsiság „,nem egyéb, mint vágyódás a tudás után, épp ezért fel kell karolni' (Réthyné, 2003, 12.o.). Amint haladunk az időben elöre a 18. század francia felvilágosodás nagy alakja, Rosseau, aki a gyermeki kíváncsiságot helyezte középpontba, mely szerinte engedni kell a gyermeket, hogy ő maga oldja meg a kérdéseket. XIX. századi polgári pedagógiában Herbart hatását érezhetjük, aki felfedezte a kognitív motiváció lényegét, az ,érdeklődés az egyetlen olyan eszköz, amellyel tartóssá tehetjük az oktatás eredményét.'(Réthyné, 2003, 13.o.). Diesterweg a tudás iránti vágy és a tanulás szeretetére fókuszált. Ahhoz, hogy ezt az érzetet a tanulóban kiváltsa, a pedagógust ösztönzi arra, hogy tanítását tegye vonzóvá, érdekessé a diák számára.

A felsorolt gondolkodók tehát úgy vélekedtek, hogy a gyerekekben él a tudás iránti vágy, azonban ennek fennmaradása, fenntartása nagymértékben függ a tanároktól, szülőktől.Hazai viszonylatban meg kell említeni Nagy László munkásságát, aki felismerte az érdeklődés motiváló szerepét a tanításban, mely szerint, ha van, az ösztönszerüen elindítja az ismeretlen utáni vágyakozást, ami létrehoz egy ismeret folyamatot.

\section{Pszichológiai megközelités}

$\mathrm{Az}$ evolúciós pszichológia egyik kiemelkedő alakja Charles Darwin (1809-1882) elméletének a lényege, hogy a természetben az élőlények versengenek egymással a fennmaradásért. Freud Sigmund pszichoanalitikus megközelítése szerint, a motivációk a személyes múltban, élettörténetben gyökereznek és felnőtt személyiséget is teljes mértékben a gyermekkori tapasztalatok határozzák meg. A drive elméletek kidolgozója Clark Leonard Hull (1884-1952) a Yale Egyetem professzora. Ezek olyan motivációs elméletek, melyek a belső tényezők fontosságára helyezik a hangsúlyt. Drive szó jelentése ösztönöz, hajt, irányít, müködtet (Fodor, 2007)

\section{Szociológiai megközelités}

A tanulási motiváció és eredményesség nagymértékben függ a környezeti hatásoktól. A családi háttér e területen való jelentőségét több vizsgálat is alátámasztotta. Coleman (1996) szintén amellett érvel, hogy a családi háttér jellege meghatározza a gyermek későbbi teljesítményét. Ezen belül kiemeli a család jövedelmi-, vagyoni helyzetét, második tényezőként az emberi tőkét, mely a szülők iskolai végzettségét takarja, harmadik összetevőként a társadalmi tőkét említi, mely leginkább a szülők gyermekeikre fordított idő és energia mennyiségében mérhető. Jelen írásunkban elsősorban a szülök emberi tőkéjét vesszük figyelembe, mint a gyerekek tanulási motivációjának prediktorát.

\section{Élettani megközelités}

Amennyiben az anatómiai viszonyokban akarjuk elhelyezni a motivációt akkor azt, kell tudnunk, hogy a limbikus rendszer (1. ábra) felelős az érzelmeinkért. Az általános motivációs 
állapot jelentős szerepet játszik a viselkedésünkben, melynek anatómiai-élettani alapja a formatio retikularis. Kísérletek igazolták, hogy a vegetatív idegrendszer bizonyos tünetekkel válaszol a motivált állapotra. Ilyen például a vérnyomás emelkedés, szapora légzés-és pulzus szám, pupillatágulat, adrenalin-és vércukor szintemelkedés, melyek által a szervezet az energiáit mozgósítja.

\section{1. ábra: Limbikus rendszer (forrás: kekneveles.net)}

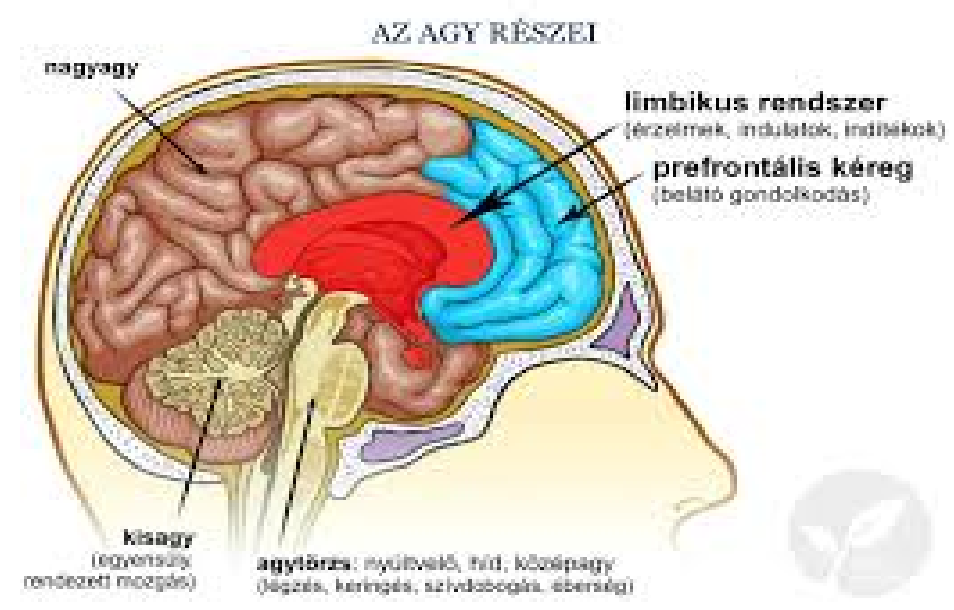

A tanulási motiváció külső és belső tényezőit ismeri a szakirodalom. Ennek bemutatásához Réthyné tipizálásához nyúlunk vissza. Írása szerint:' 'belső (intrinzik) tanulási motivációról akkor van szó, ha a motivált állapot a tanulók meghatározott személyiségjegyei vagy a tanulási helyzet sajátosságai révén jön létre. Külső (extrinzik) tanulási motiváció fennállása esetén a tanulás a ülső, kivülröl ható, magától a tanulási tevékenység lényegétől idegen,a konkrét cél előtt meghúzodó célokért történik", (Réthyné, 2003, 117-118o.)

\section{AZ EMPIRIKUS VIZSGÁLAT EREDMÉNYEI}

Kutatásunkban a fentebb említett külső és belső motívációk feltárására a következő kérdést tettük fel: „Melyek azok a tényezők, amelyek szerepet játszanak a tanulásodban?”.Arra kértük a tanulókat, hogy a felsorolt lehetőségek közül a három legfontosabb tényezőt jelöljék meg. A lehetséges első öt válasz a külső, míg a fennmaradó három a belső motiváló tényezők csoportjába tartozik. Láthatjuk a válaszok alapján, hogy a megkérdezett tanulók döntő többségét egy belső erő hatja a tanulásban, amely nem más mint a köteleségtudat és a sikeressé válás. Azonban kiemelendő a jó jegyek jelentősége, amely igen motiváló jelentőséggel bír a tanulók teljesitményében. Itt emelnénk ki a hatékony pedagógus szerepét. A jó jegy, a dicséret, a jutalom, mint extrinzik faktor mega erővel hathat a diák munkájára. (2.ábra)

2.ábra. Melyek azok a tényezők, amelyek szerepet játszanak a tanulásodban? (fö). (forrás: Pálosi és R. Fedor 2017 saját vizsgálat) 


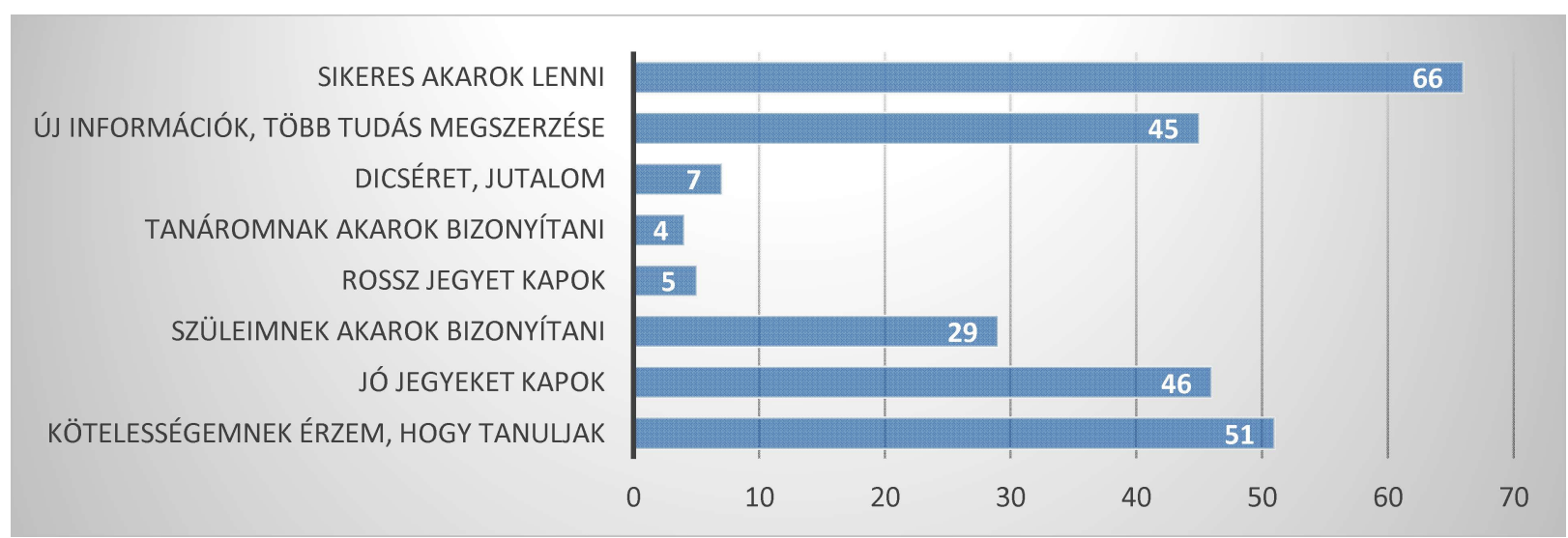

A következő három kérdés, mely a tanuláshoz kapcsolódó motivációs tényezőkön belül a tárgyi dolgokra kérdez rá, szintén ezt a gondolatmenetet követi. A megkérdezettek 57\%-nak nem tettek ígéretet a szülei, családtagjai a jó tanulmányi éredményeiért illetve nem is várják el a fiatalok, hogy bármiféle jutalomban is részesítsék öket. Azonban 32\%-nak azt ígérték a szülők, hogy a jó teljesítményét honorálják, ugyanakkor az ehhez a csoporthoz tartozó fiatalok nem tarják fontosnak a tárgyi jutalmat. Pozitív csalódás ez a mai anyagias világba, ahol minden arról szól, hogy ha valamit csinálunk azért honorárium jár. (3.ábra)

3.ábra. Tettek-e valaha igéretet szüleid,családtagjaid, rokonaid,hogy amennyiben jól tanulsz kapsz valamit?(forrás: Pálosi és R. Fedor 2017 saját vizsgálat)

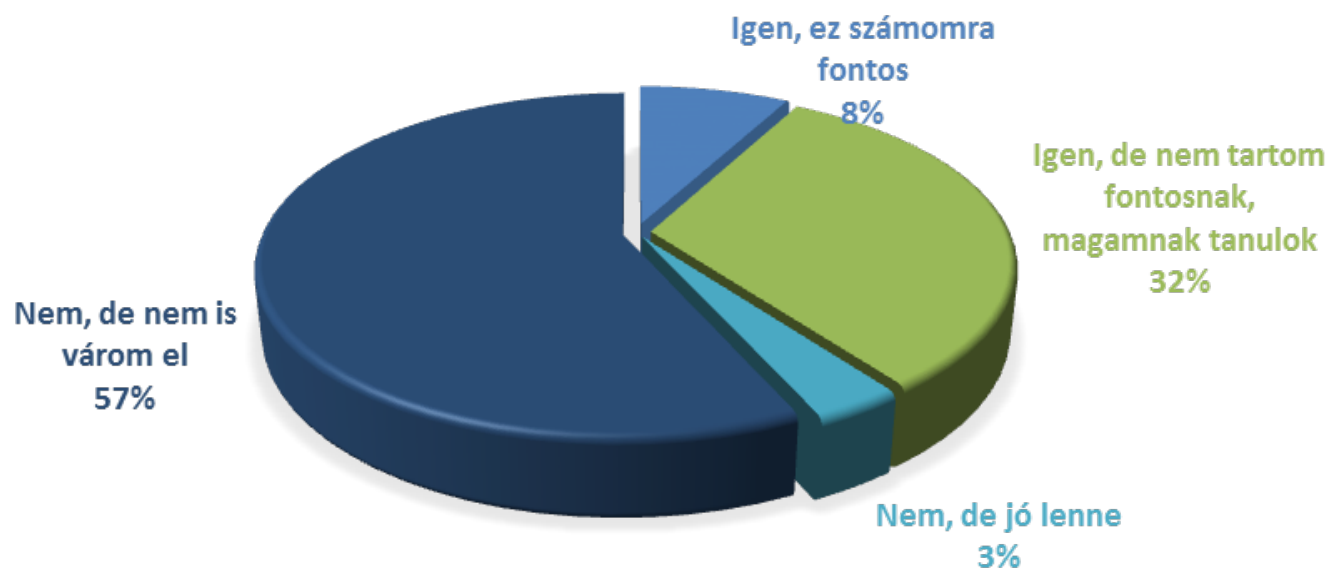

Nyitott kérdésben vártuk a válaszok széles skáláját, a tekintetben, hogy mi mindent fognak felsorolni a válaszadó diákok, amelyeket jutalomként adhat egy szülő a gyermekének ha kiemelkedően teljesít. A 88 föből, 65 nem válaszolt erre a kérdésre azaz, gyakorlatilag 65 fö semmilyen jutalmat nem kap teljesítményéért. A maradék 23 fó válaszaitból kiderül hogy a tárgyi dolgok, mint a pénz a ruha mellett megjelent a dicséret is.

Mindezek ismeretében, rákérdeztünk a tanulók tanulmányi eredményeire is. Azt kértük, hogy az utolsó félévet vették figyelembe. A diákok közül mindösszesen egy fó volt, aki a közepes érdemjegyet jelölte meg. 25 fö kitünő, 36 jeles és 22 tanuló jó minősítéssel büszkélkedhet, 4 fö nem válaszolt. Ezen a ponton érdemes megemlíteni, hogy a válszadó 
fiatalok, kiemelkedő átlagostanulmányi eredményt produkáló gimnázium tanulói, ezért vizsgálatunk eredményei nem általánosíthatóak a végzős fiatalok teljes csoportjára.

Arra a kérdésre, hogy elégedett-e a tanulmányi eredményeivel 30 fó nemmel válaszolt. Ami azt jelentheti, hogy a jeles tanulók körében is akadnak diákok, akik még jobb teljesítményre vágynak.

Arra is kiváncsiak voltunk, hogy mennyire elégedettek az életükkel a diákok. Válaszaikból a következők derülnek ki: Összeségében a megkérdezett fiatalok jelentős többsége elégedett az életével. 39\% nagyon, 51\% az inkább elégedett kategóriát jelölte meg. 8\%-uk inkább nem vagy egyáltalán nem elégedett (4.ábra).

4.ábra.Összeségében mennyire vagy elégedett az életeddel?(forrás: Pálosi és R. Fedor 2017 saját vizsgálat)

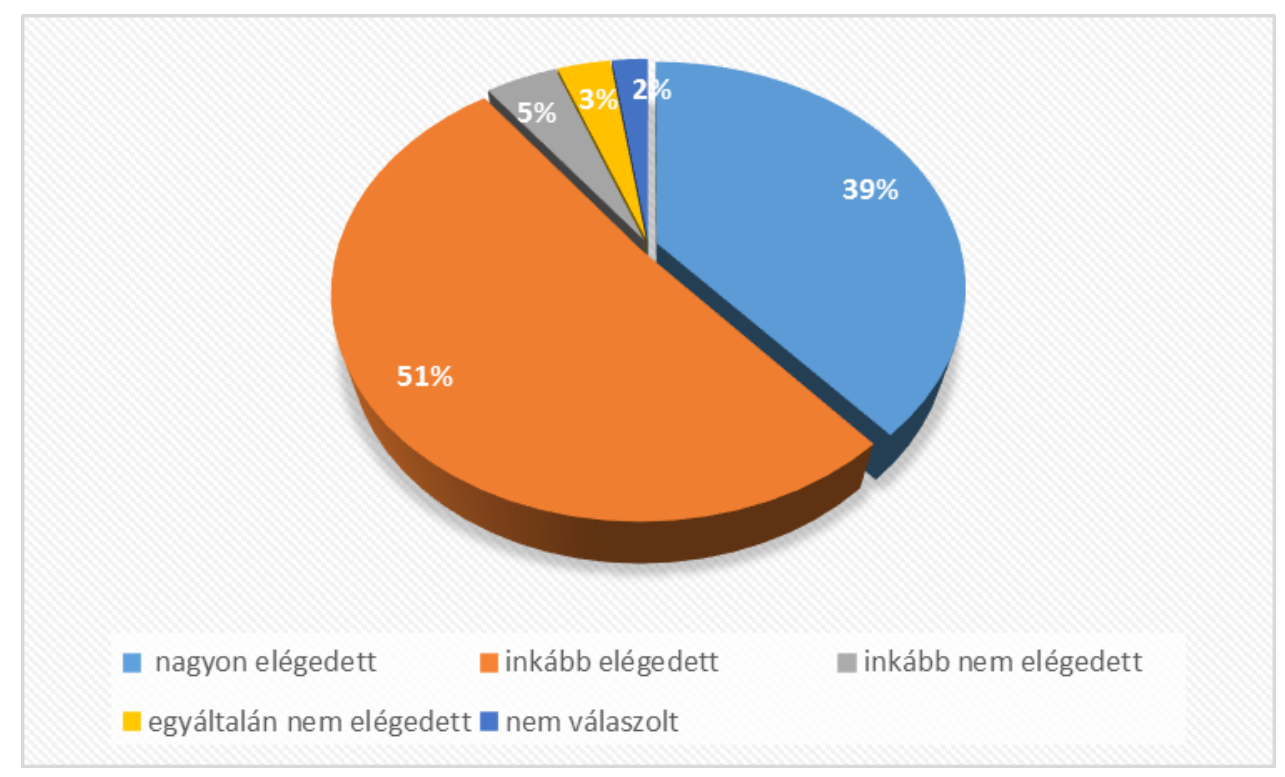

Az elégedettség és a jövedelmi helyzet $(\mathrm{p}=0,000)$ valamint a fiúk és lányok elégedettsége között szignifikáns összefüggést tapasztaltunk $(\mathrm{p}=0,000)$.

\section{1. táblázat. Élettel való elégedettség (\%). Forrás.Szerzök.}

\begin{tabular}{|l|r|r|}
\hline & Nö & \multicolumn{2}{|c|}{ Férfi } \\
\hline Nagyon meg vagyok elégedve & 44,4 & 34,4 \\
\hline Inkább elégedett vagyok & $\mathbf{4 8 , 1}$ & $\mathbf{5 9 , 4}$ \\
\hline Inkább nem vagyok elégedett & 3,7 & 3,1 \\
\hline Egyáltalán nem vagyok elégedett & 3,7 & 3,1 \\
\hline Nem tudom, nem válaszolok & 0,0 & 0,0 \\
\hline
\end{tabular}

Az 1. táblázatban látható, hogy bár mindként nemre jellemző az elégedettség, a legelégedettebb válaszlehetőséget nagyobb arányban választották a lányok, mint a fiúk. A fiúkra inkább egy óvatosabb válaszadói attitüd jellemző.

Személyiségjegyek 
A következő kérdések a személyiség, jellemvonások téma köré csoportosultak. Azonban mielött az eredményeket megosztanánk egy kis pszichológiai megjegyzést szeretnénk adni, miszerint egyes stabil személyiségvonások összekapcsolhatók az arousal rendszer müködésében fennálló egyéni tulajdonságokkal. Az arousal jelentése általános agyi aktivitási szint és rendszer, azaz a szervezet éberségi állapota (mipszi.hu). Ez az ismeret pedagógiai szempontból igen meghatározó lehet a tanulónak a feladat megoldásában illetve a kitüzött cél megvalósításában. A motiváció feltárására különböző tesztek állnak a rendelkezésünkre, mint például önjellemzési, személyiségvizsgáló tesztek, szorongás vizsgálatára alkalmas kérdőívek. Két csoportot szeretnénk kiemelni: a kudarckerülők és sikerorinetáltak csoportját, mellyel mérhető a teljesítménymotiváció. Azokat az egyéneket, akik közepes nehézségü feladatokat szívesen oldanak meg, kitartóak, sorozatos kudarcok nem törik le, akik nem adják fel a kitüzött célt, hanem inkább küzdenek érte, őket sikerorientáltaknak nevezzük. Ezzel ellentétben a kudarckerülő személyeknél a közepes nehézségü feladatoknál a legalacsonyabb a motiváció. A kudarcot saját képességeik hiányának tekintik, egy-egy sikerről nehezen hiszik el, hogy saját maguknak köszönhetik (Fodor, 2007).

Ehhez kapcsolódóan arra voltunk kiváncsiak, hogy a felsorakoztatott kijelentésekről hogyan gondolkodnak a diákok. (2.táblázat). Láthatjuk, hogy a válaszadók többsége a sikert a saját hozzáállásának tulajdonítja nem a feladat nehézségétől teszi függővé. Ez a fentebb leírtak alapján egyfajta sikerorientált attitüdöt takar. Ezt megerösíti az a tény, hogy mindössze heten gondolták azt, hogy a jó eredményhez szerencse kell. Az eredményekböl az is látható, hogy a válaszadók a tanulásra szánt időnek is kiemelkedő jelentőséget tulajdonítottak eredményeik alakulásában. Ehhez kapcsolódóan azt is megkérdeztük, hogy naponta mennyi időt fordítanak tanulásra. A válaszok igen széles skálán mozogtak, a legrövidebb 5-10 perctől egészen a napi 7 óráig terjedt az időintervallum. ${ }^{3}$

2. táblázat: Az alábbiak közül válaszd ki azt, amelyik a leginkább jellemzö Rád?.(forrás: Pálosi és R. Fedor 2017 saját vizsgálat)

\begin{tabular}{|l|r|}
\hline \multicolumn{1}{|c|}{ Állítások } & fó \\
\hline Ahhoz, hogy jó eredményt érjek el, rajtam múlik és nem a feladat nehézségén. & 55 \\
\hline Ahhoz, hogy jó eredményt érjek el ahhoz szerencse is kell. & 7 \\
\hline Ha nem szánok elég időt a tanulásra az a teljesítményemben is megmutatkozik & 16 \\
\hline Ha rosszul sikerül a dolgozatom/vizsgám, akkor magamat hibáztatom & 6 \\
\hline Nem válaszolt & 4 \\
\hline
\end{tabular}

Nemekre lebontva az otthoni tanulás időtartamát azt tapasztaltuk, hogy a fiúk saját bevallásuk szerint kevesebb tanulással is beérik, mint a lányok. $(\mathrm{p}=0,022)$ Előbbiek közül a legnépesebb csoport a maximális egyórát, utóbbiak a maximális 3 órát jelölték meg a legnagyobb arányban.

A következő kérdésünkben arra próbáltunk választ kapni, hogy a motivált állapotot milyen testi tünetek kísérik az érintett diákok esetében. A többség arról számolt be, hogy bár előfordul vele, hogy izgul dolgozatírás elött, de ezt az állapotot testi tünetek nem kísérik. Meglepő és elgondolkodtató, hogy második helyen szerepel a szorongás testi tünetekkel válaszlehetőség. 14 fő a magabiztosságot sejtető „,nem izgulok, nincs lámpalázam” kijelentéssel értett egyet. (3 táblázat)

\footnotetext{
${ }^{3}$ Részletes adatok feldolgozás alatt.
} 
3. táblázat: Gyakran szorongsz-e dolgozat elött? Vannak-e testi tüneteid (émelygés, hasmenés, hasfájás, fejfájás)? (forrás: Pálosi és R. Fedor 2017 saját vizsgálat)

\begin{tabular}{|l|r|}
\hline \multicolumn{1}{|c|}{ Állítások } & \multicolumn{1}{|c|}{ fó } \\
\hline Igen szorongok testi tünetekkel & 22 \\
\hline Szorongok, testi tünetek nélkül & 16 \\
\hline Nem izgulok, nincs lámpalázam & 14 \\
\hline Néha elöfordul, hogy izgulok ez testi tünetekkel is jár & 6 \\
\hline Néha előfordul, hogy izgulok, de testi tünetek nélkül & 26 \\
\hline Nem válaszolt & 4 \\
\hline
\end{tabular}

Valószinű ez köszönhető az iskola versenyszellemének is, mint az kiderül a korábbi értékekből, mely szerint igen magasan kvalifikált, átlag feletti tanulmányi eredménnyel rendelkező, jó képességü gyermekek kerülnek ebbe a gimnáziumba.

Válaszadóink vélemény nyilvánításából egyértelmüen kiderül, hogy a lányok dolgozatírás, felelés előtt szorongóbb attitűdöt mutatnak, mint a fiúk (4.táblázat). A Khi-négyzet próba lefuttatása szignifikáns kapcsolatot mutat $(\mathrm{p}=0,000)$ a szorongás és a nemhez való tartozás között. Ezen belül két szembetünő kijelentéshez kapcsolódó választ emelünk ki. Az egyik a legerösebb szorongást/félelmet takaró kategória: „Igen szorongok testi tünetekkel”, a másik ennek ellenkezője: „Nem izgulok, nincs lámpalázam”, a nyugodt, tét nélküli, lazább vélemény. Előbbi a lányok több mint egyharmadát érinti, míg a fiúknál ez az arány $10 \%$ alatt van. Utóbbi, a fiúkra jellemző inkább. Közel egyharmaduk nyilatkozott, úgy, hogy nem igazán szokott ilyen helyzetekben izgulni. A lányok 5,6\%-a válaszolt hasonlóan. Az okok magyarázatára nem térünk ki részletesen, de azt gondoljuk, hogy eredmények nem meglepőek. A lányok fokozott normakövetése, megfelelési vágya és az ennél lazább fiúk macho viselkedése érhetö talán tetten.

4. táblázat: Gyakran szorongsz-e dolgozat elött? Vannak-e testi tüneteid (émelygés, hasmenés, hasfájás, fejfájás)? (forrás: Pálosi és R. Fedor 2017 saját vizsgálat)

\begin{tabular}{|l|r|r|}
\hline & Nők & \multicolumn{1}{|c|}{ Férfiak } \\
\hline Igen szorongok testi tünetekkel & $\mathbf{3 5 , 2}$ & $\mathbf{9 , 4}$ \\
\hline Szorongok, testi tünetek nélkül & 20,4 & 15,6 \\
\hline Nem izgulok, nincs lámpalázam & $\mathbf{5 , 6}$ & $\mathbf{3 1 , 3}$ \\
\hline Néha elöfordul, hogy izgulok ez testi tünetekkel is jár & 5,6 & 12,4 \\
\hline Néha elöfordul, hogy izgulok, de testi tünetek nélkül & 31,5 & 31,3 \\
\hline Nem válaszolt & 1,9 & 0,0 \\
\hline
\end{tabular}

\section{Továbbtanulási szándékok, munkaerö-piaci elvárások}

Napjainkban a médiában gyakran hallani, hogy kevés a szakember, akik pedig valamilyen jó szakképzettséggel rendelkeznek elhagyják az országot a jobb megélhetés reményében. Ehhez kapcsolódóan megkérdeztük a fiatalokat arról, hogy tervezik-e, hogy az érettségi után tovább fognak tanulni, valamint, hogy tervezi-e, hogy tanulmányaikat külföldön folytatják majd?

A megkérdezettek körében a 88-ból 72 fó szeretné a tanulmányait folytatni valamelyik alapképzésben illetve felsőoktatási képzésben Azt, hogy hol található az intézmény, melyben tanulni szeretne, 39 fö válaszolta Debrecent, Budapestet 37 fö jelölte meg és külföldi tanulmányokban csupán 8 fő gondolkozik. Egy-egy fö Pécset és Kecskemétet jelölte meg. 
Azon belül is, hogy melyik területen szeretnének továbbtanulni elsőnként jelölték meg az egészségügyet, második a gazdasági tudományterület és harmadik helyen az informatika szerepelt. Ezek az adatok azt igazolják, hogy elsősorban az adott régióban valamint a fővárosban kívánnak továbbtanulni a fiatalok.

Azonban a következő kérdés adatai ellentmondásba kerültek az előzővel. Miszerint nyolc tanuló képzeli el azt, hogy külföldön szeretné folytatni a tanulmányait, de ezek mellett 45 hallgató válaszolt arra a kérdésre, hogy ha külföldön szeretne tanulni, akkor melyik országban képzeli el ezt. Az alábbi táblázatban láthatjuk, hogy számos ország neve felkerült a listára. Fej-fej mellett vezet Amerika és Anglia. 43 fő nem válaszolt. (5.táblázat).

5. táblázat: Ha külföldön szeretnél tanulni, melyik országban? (forrás: Pálosi és R. Fedor 2017 saját vizsgálat)

\begin{tabular}{|l|r|l|r|}
\hline \multicolumn{1}{|c|}{ Ország } & Fö & \multicolumn{1}{|c|}{ Ország } & Fö \\
\hline Amerika & 12 & Spanyolország & 1 \\
\hline Anglia & 12 & Ausztrália & 1 \\
\hline Németország & 10 & Japán & 1 \\
\hline Franciaország & 3 & Olaszország & 1 \\
\hline Dánia & 2 & Hollandia & 1 \\
\hline Ausztria & 1 & Nem válaszolt & 43 \\
\hline
\end{tabular}

A fent közölt adatok ellenvetése az alábbi kérdésben tisztázódni látszik, hogy miért szeretnének más országban tanulni a fiatalok. Több lehetséges válasz is adható volt. (6.táblázat) A külföldi tanulmányokkal a cél elsőként a magasabb életszínvonal elérése (46 fö). Ez alátámasztja a korábbi kutatások eredményeit. Az okok rangsorában második helyen a „,világot szeretnék látni” kategóri áll (40 fö) és ezt követi a tanulmányok befejezését követő könnyebb munkavállalási, karrierépítési lehetőség (28fó).

6. táblázat: Miért szeretnél külföldön tanulni? (forrás: Pálosi és R. Fedor 2017 saját vizsgálat)

\begin{tabular}{|l|r|}
\hline \multicolumn{1}{|c|}{ Állítások } & \multicolumn{1}{|c|}{ fó } \\
\hline Külföldi diploma megszerzése miatt & 13 \\
\hline Világot szeretnék látni & 40 \\
\hline A magasabb szintü, minőségü oktatás miatt & 25 \\
\hline A külföldi tanulmányok nagyobb lehetőséget adnak az áttelepülésre & 19 \\
\hline Jobban felszereltek a laboratóriumok, könyvtárak & 15 \\
\hline Magasabb az életszínvonal & 46 \\
\hline Demokrácia és szólásszabadság van & 6 \\
\hline Olyan felsőoktatási intézmény van, ami közel van a lakóhelyemhez & 0 \\
\hline A tanulmányok befejeztével könnyebb munkát vállalni, karriert építeni & 28 \\
\hline Könnyebb az önmegvalósítás, a képességeim fejlesztése & 13 \\
\hline Biztonságosabb, távol van a háborús konfliktusoktól & 2 \\
\hline Könnyebben lehetek független, önálló & 14 \\
\hline Mozgalmas az élet, lehetőség van érdekesen eltölteni a szabadidőt & 24 \\
\hline Nincs korrupció az oktatásban & 5 \\
\hline
\end{tabular}


A munakerö-piaci kitekintés kapcsán megkérdeztük a végzős fiatalokat, hogy hol szeretnének dolgozni a diploma megszerzése után (5. ábra). Vezető helyen szerepel a külföldi cég majd ezt a követi a saját üzleti vállalkozás. Érdekes, hogy a családi vállakozás, mint az egyik lehetséges munkahely az utolsó helyre került a ranglistán. Talán ez annak tudható be, hogy pszichológiailag ezt a korosztályt jellemzi az önállósodás, a függetlenség, leválás a családról, az ego kibontakozása és érvényesülése.

5. ábra. Hol szeretnél dolgozni a diploma megszerzése után?(fö) (forrás: Pálosi és R. Fedor 2017 saját vizsgálat)

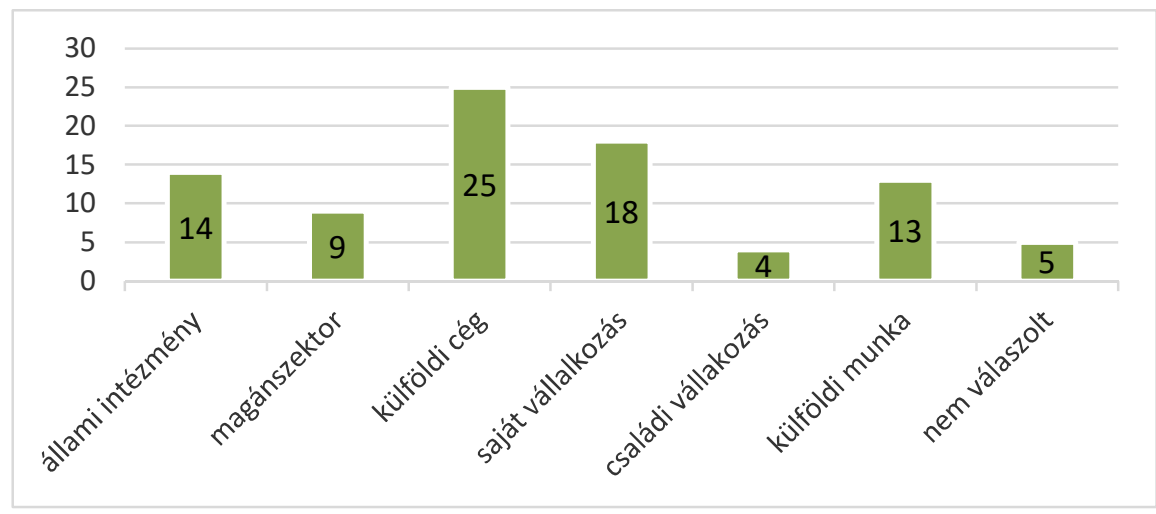

Arról, hogy milyen esélyeik vannak a jövőre vonatkozóan céljaik megvalósításában, igen optimistán vélekednek a diákok. Az erre vonatkozó adatokat a 7. táblázatban foglaltuk össze.

7. táblázat: Hogy gondolod, mennyire sikerül megvalósitani a jövőre vonatkozó terveidet?

(forrás: Pálosi és R. Fedor 2017 saját vizsgálat)

\begin{tabular}{|l|r|}
\hline \multicolumn{1}{|c|}{ Állítások } & fö \\
\hline Nagyon nagy eséllyel sikerül & 5 \\
\hline Nagy eséllyel sikerül & 58 \\
\hline Közepes eséllyel sikerül & 10 \\
\hline Kevés eséllyel sikerül & 1 \\
\hline Nagyon kevés eséllyel sikerül & 0 \\
\hline Nem válaszolt & 14 \\
\hline
\end{tabular}

A vizsgálatunk eredményeinek megértéséhez szükségesnek tartottuk, hogy a fiatalok társadalmi, szociokulturális jellemzőire is rákérdezzük. Ehhez kapcsolódóan érdemes kitekinteni a családi háttérre, mely nagy hatással bír a fiatalok életére. Értve ezalatt a fent említett témákat. Korábbi kutatások igazolták, hogy az „eltérő szociokulturális környzetből származó gyermekek készségeinek, képességeinek fejlettségében jelentős különbségek vannak".(Józsa, 2007:150). Fejes József és munkatársai a családi háttér tanulási motivációra gyakorolt hatását elemezték a tanulók önjellemzéseire alapozva (Józsa,2007:150). Láczay és R. Fedor (2017) összefüggést talált a szülőkkel való kapcsolat minősége és a különböző kockázati tényezők (alkohol, drog fogyasztás, dohányzás) jelenléte között.

Saját vizsgálatunkban a családi háttér meghatározó faktoraként a szülők iskolai végzettségét (1sd.12.táblázat) és beosztását tekintettük. (8. táblázat) 
8. táblázat: Szülők iskolai végzettsége (fö). (forrás: Pálosi és R. Fedor 2017 saját vizsgálat)

\begin{tabular}{|l|r|r|}
\hline \multicolumn{1}{|c|}{ Iskolai végzettség } & \multicolumn{1}{c|}{ Apa } & \multicolumn{1}{c|}{ Anya } \\
\hline Nem befejezett általános iskola & 0 & 0 \\
\hline Általános iskola & 0 & 1 \\
\hline Szakiskola/szakmunkásképzö & 6 & 1 \\
\hline Szakközépiskola & 4 & 4 \\
\hline Gimnázium & 6 & 7 \\
\hline Technikum & 6 & 3 \\
\hline Főiskola, alapképzés (Ba/Bsc) & 17 & 23 \\
\hline Egyetem,mesterképzés MAa/MSc) & 25 & 28 \\
\hline Tudományos (PhD./doktori & 20 & 18 \\
\hline Nem válszolt & 4 & 3 \\
\hline
\end{tabular}

A szülők iskolai végzettség és beosztás szerinti mintázata (9.táblázat) egy erőteljes magasan kvalifikált szülői háttérről árulkodik. A szülők több mint a fele, (apa 62 fö, anya 69 fö esetében) minimum föiskolai vagy annál magasabb végzettséggel rendelkezik.

9. táblázat: A szülők beosztása (fö).(forrás: Pálosi és R. Fedor 2017 saját vizsgálat)

\begin{tabular}{|c|c|c|}
\hline Beosztás & Apa & Anya \\
\hline Igazgató, cégvezetőségi tag, vezető, képviselő & 16 & 12 \\
\hline Felsőfokú végzettségü szakember (tanár, orvos, jogász, író) & 25 & 38 \\
\hline Mérnök, középszintü hivatalnok & 6 & 6 \\
\hline Alsóbb szintü hivatalnok (titkár, pénztáros) & 2 & 6 \\
\hline Cégtulajdonos & 11 & 5 \\
\hline Kereskedelmi vagy szolgáltatási dolgozó & 11 & 11 \\
\hline Szakmunkás & 6 & 1 \\
\hline Betanított, segédmunkás, mezőgazdasági munkavállaló & 1 & 2 \\
\hline Gazdálkodó (farmer, őstermelő) & 1 & \\
\hline Munkanélküli & & 1 \\
\hline Nyugdíjas & 1 & \\
\hline Egyéb (adja meg) & meghalt:2 & $\begin{array}{r}\text { óvónő, } \\
\text { pénzügyi } \\
\text { menedzser }\end{array}$ \\
\hline Nem válaszolt & 6 & 4 \\
\hline
\end{tabular}

A szülői példa, az otthoni minta követése igen meghatározó szerepet játszik a gyermekek életében. A kavlifikált, szakmai sikereket elérő szülők erős motiváló erőt jelenthetnek gyermekeik számára a tanulmányi életút eredményessége és a későbbi pályaválasztásra vonatkozóan is. Erre különösen ha azt felnőtt fejjel teszi meg az édasanya vagy édesapa. Az iskolai végzettségből következik a szülők beosztása, mely szintén döntő többségben (apa 41 fö, anya 50 fö) minimum tanár, orvos, jogász vagy valamilyen vezetői pozícióban dolgozik a szülők meghatározó része. Mind az iskolai végzettséget, mind a beosztást tekintve a házastársak között az anyák oldalára billen a mérleg.

A staisztikai próba szignifikáns kapcsolatot mutat a diákok teljesítménye az anya $(p=0,000), \quad$ az apa iskolai végzettségével $(p=0,000)$ és az anya beosztásával $(p=0,000) . A z$ 
apa beosztása nem meghatározó a teljesítmény szempontjából $(\mathrm{p}=0,099)$ a gimnáziumba járó fiatalok tekintetében.

Az iskolai végzettséget magyarázó változóként viszgálva azt látjuk, hogy az anya egyetemi végzettsége egyértleműen kitünő teljesítményt valószinűsít a tanulóknál. A kitünő eredményt elérő gyerekek 40\%-nak egyetemet végzett az édesanyja. Második helyen a tudományos fokozattal bíró anyák gyerekei vannak $28 \%$. Hasonló összefüggést és arányokat találtunk az apák vonatkozásában is.

Az anya beosztását vizsgálva azt látjuk, hogy a „felsőfokú szakember „, kategóriájába tartozó anyák gyermekei teljesítenek a legjobban (48\%), de ami érdekes, a közepes tanulmányi eredménnyel bíró gyerekek többsége is ilyen beosztású anyával bír. Utóbbi esetben meg említem, hogy az egy cellára jutó elemszám igen kicsi. A megosztott második hely a beosztási hierarchi csúcsán lévő ,igazgatói, cégvezetőségi,, pozícióban valamint a középmezőnyben elhelyezkedő „kereskedelmi és szolgáltatási területen dolgozó” anyák gyermekei állnak 20-20\%-uk bír kitünő eredménnyel. Öket követik a közép és alsó szintü hivatalnokok gyermekei 4-4\%-kal, és az egyéb kategória szintén 4\%-kal.

A család jövedelmi helyzete és a tanulmányi eredmény közötti összefüggést nem bizonyítják az adataink, a válszadó debreceni diákok tanulmányi eredménye nem függ a család anyagi helyzetétöl $(\mathrm{p}=0,653)$.

\section{Konklúziók}

Írásunkban a fiatalok tanulási motivációit, munkaerő-piaci elvárásait vizsgáltuk egy debreceni gimnázium végzés előtt álló hallgatói körében. A 88 fő diák véleménynyilvánításából egy igen magas tanulmányi eredménnyel és magasan kvalifikált szülői háttérrel bíró diákcsoport rajzolódott ki előttünk. Kutatásunk eredményeinek jelentős része ezekkel a jellemzőkkel szorosan összefügg. Ugyanezen jellemzők jelentik eredményeink korlátait is. E szerint vizsgálatunk jelenlegi megállapításai nem terjeszthetők ki a végzős fiatalok csoportjára általában. Ennek a kritériumnak akkor felelnek meg majd az adataink, ha az általunk tervezett további iskolánk diákjait is megkérdezzük az érintett témában.

Vizsgálatunk alapján az alábbi következtetéseket vonjuk le: a fiatalok tanulásának elsődleges mozgatórugója a sikerek elérése, a jó érdemjegy megszerzése mellett a jó teljesítménnyel kapcsolatos kötelességtudat. Ehhez kapcsolódóan a fiatalok egy része szorong és testi tüneteket is produkál dolgozatírás elött, mely vélhetően összefügg azzal, hogy az elért eredménynek tétje van. A megmérettetés előtti szorongás inkább a lányokra volt jellemző.

Motiváló tényezőként a tárgyi dolgok háttérbe kerülnek és a belső indítatás, a siker és az élettel való elégedettség kerül előtérbe.

A családi faktorok közül a szülők iskolai végzettségét tekintve elmodhatjuk, hogy az édesanyák egyetemi végzettsége egyértlemüen kitűnő teljesítményt valószinűsít. Mindemellett statisztikailag meghatározó kapcsoolatot találtunk az apa iskolai végzettsége, az anya beosztása és a diák teljesítménye között.

A külföldi karrier elsősorban a jobb megélhetés és a világ megismerése miatt népszerü.

A fiatalok általában elégedettek az életükkel és úgy vélik, hogy nagy eséllyel sikerül megvalósítaniuk a jövőre vonatkozó terveiket.

Rövid távú céljaink között szerepel, hogy elemző munkánkat kiterjesztjük s eredményeinket összehasonlítjuk a fentebb bemutatott általános gimnáziumba járó és a jelenleg feldolgozás alatt lévő szakgimnáziumban tanuló diákok válaszaiból nyert eredményekkel, melyből némi ízelítőt jelenlegi írásunkban is adtunk. További tervünk, hogy eredményeinket összevetjük a Youth in Central and Eastern European Cross-border Areas kutatásban résztvevő nyíregyházi 
fiatalok jellemzőivel. Az előzetes összehasonlító kitekintésünk jelentős különbségek jelenlétét sejtetik e három alminta tekintetében.

\section{IRODALOM}

Coleman, J. S. (1996): A társadalmi tőke. In: Lengyel György - Szántó Zoltán (szerk). A gazdasági élet szociológiája. BKE Szociológiai és Szociálpolitikai Tanszék, Budapest, 99129.

Engler, Á., R. Fedor, A.,_Markos, V. (2016): Vision and plans of the young peole os Nyíregyháza about thetir futre.Youth in central and Eastern Europe. Sociologocal studies (2) pp. 118-135.

Fodor, L.ó (2007) Fejezetek a motivációkutatásból Gondolat Kiadó Bp.

Józsa, K. (2007) Az elsajátítási motiváció Műszaki Kiadó

Kovács, K., Dusa, Á., Ludescher. G.,(2016): Globalization, Localization and Individualization among High School Students in Nyíregyháza. Youth in central and Eastern Europe. Sociologocal studies 5:(2) pp. 98-117. (2016

Láczay, M., R. Fedor, A. (2017):_A szabolcs-szatmár-beregi fiatalok bizalmi kapcsolatainak bemutatása kockázati tényezők elemzése alapján: prediktorok és protektorok egy vizsgálat adatbázisának több dimenziós elemzésében. In: Fábián Gergely, Szoboszlai Katalin, Hüse Lajos (szerk.) A társadalmi periférián élö gyermekek és fiatalok rizikómagatartásának háttere.

Nyíregyháza: Periféria Egyesület, 2017. pp. 73-90.

Réthy Endréné (2003): Motiváció, Tanulás, Tanítás Miért tanulunk jól vagy rosszul Nemzeti Tankönyvkiadó Bp. 